\title{
PENGARUH PERSEPSI KONSUMEN MENGENAI ATRIBUT PRODUK TERHADAP KEPUTUSAN PEMBELIAN BUAH ALPUKAT MENTEGA SECARA ONLINE \\ (Suatu Kasus Pada Konsumen Kojama Shop)
}

\section{THE INFLUENCE OF CONSUMER PERCEPTIONS REGARDING PRODUCT ATTRIBUTES ON ONLINE PURCHASE DECISIONS OF AVOCADO BUTTER (A Case In Kojama Shop Consumers)}

\section{Belva Ilaika Rahmadini Girawan*, Pandi Pardian, Agriani Hermita Sadeli, Dika Supyandi ${ }^{4}$}

\author{
Program Studi Agribisnis, Fakultas Pertanian, Universitas Padjadjaran \\ *E-mail: belva17003@mail.unpad.ac.id \\ (Diterima 11-1-2021; Disetujui 18-1-2021)
}

\begin{abstract}
ABSTRAK
Produk pertanian terutama buah saat ini cenderung dinikmati secara segar dan variasi produk olahan cukup jarang ditemukan terlebih pada buah alpukat. Kini penjualan buah segar termasuk alpukat tidak hanya tersedia pada pasar tradisional atau pasar modern saja melainkan juga tersedia di toko online. Salah satu pelaku bisnis yang memanfaatkan sosial media sebagai platform penjualan buah adalah Kojama Shop. Tujuan dari penelitian ini adalah untuk mengetahui karakteristik konsumen buah alpukat mentega di Kojama Shop dan menganalisis pengaruh konsumen mengenai atribut produk terhadap keputusan pembelian buah alpukat mentega secara online di Kojama Shop. Teknik sampling yang digunakan pada penelitian ini adalah non probability sampling yaitu convenience sampling atau dengan kriteria orang tersebut merupakan konsumen buah alpukat di Kojama Shop. Jenis penelitian ini adalah penelitian ini adalah penelitian kuantitatif dengan teknik analisis statisik deskriptif distribusi frekuensi dan analisis regresi linear berganda. Hasil penelitian menunjukkan masing-masing variabel kualitas produk, harga produk, dan citra merek berpengaruh terhadap keputusan pembelian buah alpukat mentega di Kojama Shop.
\end{abstract}

Kata kunci : persepsi konsumen, alpukat mentega, regresi linear berganda, Kojama Shop

\begin{abstract}
Current agricultural products, especially fruit, tend to be enjoyed fresh and a variety of processed products is quite rare in avocados. Now the sale of fresh fruit including avocado is not only available in traditional or modern markets, but is also available in online stores. One of the business players who use social media as a platform for selling fruit is the Kojama Shop. The purpose of this study was to see the response of consumers of avocado butter at the Kojama Shop and to analyze the influence of consumers on product attributes on purchasing decisions for avocado butter online at the Kojama Shop. The sampling technique used in this study is nonprobability sampling, namely convenience sampling or with the criteria that the person is an avocado consumer at the Kojama Shop. This type of research is a quantitative research with descriptive statistical analysis techniques of frequency and multiple linear regression analysis. The results showed that each variable of product quality, product price, and image had an effect on the purchase decision of avocado butter at Kojama Shop.
\end{abstract}

Keywords: consumer perception, avocado butter, multiple linear regression, Kojama Shop 


\section{PENDAHULUAN}

Produk pertanian terutama buah saat ini cenderung dinikmati secara segar dan variasi produk olahan cukup jarang ditemukan terlebih pada buah alpukat. Kini penjualan buah segar termasuk alpukat tidak hanya tersedia pada pasar tradisional atau pasar modern saja melainkan juga tersedia di toko online. Tempat penjualan online menjadi alternatif konsumen dalam membeli produk segar. Sejalan dengan perkembangan teknologi informasi pada era globalisasi ini yang menyebabkan perubahan secara pesat, terutama pada cara memperoleh informasi dan berkomunikasi. Salah satu hasil perkembangan teknologi adalah internet dimana internet mendorong terjadinya inovasi dalam berbagai aktivitas. Internet memiliki sejumlah manfaat yang dapat dirasakan oleh seluruh lapisan masyarakat dari berbagai bidang, mulai dari memudahkan pekerjaan hingga pemenuhan kebutuhan hidup sehari-hari. Keberadaan internet mempermudah aktivitas bisnis yang menuntut para pelakunya untuk terus melakukan inovasi.

Dewasa ini berbagai bisnis yang memanfaatkan platform online sebagai tempat berjualan sudah sangat banyak bermunculan. Platform-platform tersebut memudahkan semua pelaku yang terlibat di dalam proses jual beli suatu produk. Produsen tidak perlu mengeluarkan tenaga, waktu, dan biaya yang lebih dalam hal melakukan pemasaran dan promosi barang. Hal tersebut dapat dilakukan melalui platform media sosial ataupun e-commerce. Macam-macam jenis produk dijual di platform online mulai dari kebutuhan sandang, pangan, hingga papan. Internet dan sosial media membantu produk-produk kebutuhan tersebut untuk diterima secara global dan memiliki basis pelanggan yang luas (Bulsara \& Trivedi, 2016). Pola berbelanja bergeser dari berbelanja di ritel konvensional ke ritel online yang lebih mudah diakses kapan saja dan dimana saja.

Kebutuhan akan bahan pangan merupakan salah satu kebutuhan yang dapat dipenuhi melalui toko online. Mulai dari produk bahan mentah seperti buah-buahan dan sayur-sayuran hingga produk olahan jadi semua tersedia di berbagai platform online. Idealnya dalam membeli produk segar, masyarakat mementingkan kualitas dari produk tersebut baik sayur, buah, maupun daging sehingga berbelanja produk pangan yang segar masyarakat lebih memilih untuk 
berbelanja di toko konvensional. Kekhawatiran utama dari berbelanja sayur dan buah secara online adalah konsumen tidak dapat melakukan sentuhan fisik secara langsung dimana sayur dan buah ini memiliki karakteristik yang mudah rusak (Bulsara \& Trivedi, 2016).

Salah satu pelaku bisnis yang memanfaatkan sosial media sebagai platform penjualan buah adalah Kojama Shop. Data penjualan yang terdapat pada platform Shopee menunjukkan bahwa hingga saat ini buah alpukat mentega sudah terjual sebanyak 13.100 unit untuk produk alpukat mentega regular size $/ 2 \mathrm{~kg}$. Jumlah penjualan alpukat mentega tersebut merupakan jumlah penjualan yang paling banyak dibandingkan dengan produk buah lainnya yang terdapat di Kojama Shop.

Selera konsumen penting untuk diketahui oleh pelaku usaha. Beberapa faktor membentuk persepsi atribut produk yang dipertimbangkan oleh konsumen dalam melakukan keputusan pembelian buah alpukat mentega secara online di Kojama Shop. Berhubungan dengan fenomena yang sudah dijabarkan, maka penulis tertarik untuk mengetahui persepsi konsumen mengenai atribut produk yang meliputi kualitas produk untuk mengetahui apakah kualitas yang diberikan oleh Kojama Shop sudah baik sehingga konsumen percaya untuk berbelanja alpukat secara online, harga untuk mengetahui apakah harga yang sudah ditetapkan oleh Kojama Shop mempengaruhi konsumen untuk melakukan pembelian, dan citra merek untuk mengetahui apakah sebagai toko online yang menjual alpukat mentega Kojama Shop memiliki citra merek yang baik di mata konsumen sehingga konsumen percaya untuk membeli alpukat secara online di Kojama Shop.

\section{METODE PENELITIAN}

Pada penelitian ini objek penelitian adalah persepsi konsumen terhadap keputusan pembelian alpukat mentega secara online di Kojama Shop. Penelitian ini menjadikan konsumen Kojama Shop sebagai subjek penelitian. Tempat penelitian dilakukan di Kojama Shop yang bertempat di Jakarta Timur. Penentuan tempat lokasi dilakukan secara sengaja dimana penentuan tersebut dilakukan karena terdapat pertimbangan tertentu yang sesuai dengan tujuan penelitian (Sugiyono, 2012). Kojama Shop dipilih karena merupakan toko online yang menjual produk alpukat mentega di platform e-commerce dengan 
jumlah penjualan yang sudah banyak dan cukup terkenal di kalangan konsumen alpukat mentega.

Jenis penelitian ini adalah penilitian kuantitatif. Menurut Sugiyono (2012), penelitian kuantitatif adalah desain penelitian yang berlandaskan filsafat positivisme yang digunakan untuk meniliti populasi atau sampel tertentu dimana pengumpulan datanya dilakukan menggunakan instrumen penelitian dan analisis data bersifat kuantitatif dengan tujuan menguji hipotesis yang sudah ditetapkan.

Analisis statistik deskriptif adalah bentuk analisis dengan tujuan meringkas data dan menyajikannya dalam bentuk yang mudah dimengerti oleh pembaca (Anderson, et al, 2011). Ringkasan data tersebut dapat berupa tabel, grafik, atau numerik. Sugiyono (2012) menjelaskan statisik deskriptif juga dapat digunakan untuk membuat perbandingan tanpa adanya uji signifikansi dan tidak ada taraf kesalahan. Statistik deskriptif yang digunakan pada penelitian ini adalah analisis distribusi frekuensi. Distribusi frekuensi adalah ringkasan tabulasi dari data yang menunjukkan jumlah (Anderson, et al, 2011). Distribusi frekuensi digunakan untuk menggambarkan karakteristik responden dan menggambarkan penilaian persepsi responden terhadap variabel yang digunakan.

Analisis liniear berganda pada penelitian ini digunakan untuk memodelkan hubungan antar variabelvariabel dependen dengan variabel independennya. Teknik yang digunakan pada penelitian ini adalah survei. Survei dilakukan dengan memberikan kuesioner kepada konsumen yang pernah membeli buah alpukat mentega di Kojama Shop dan wawancara dengan pemilik Kojama Shop.

Metode pengambilan sampel atau teknik sampling yang digunakan pada penelitian ini adalah non probability sampling yaitu convenience sampling atau accidental sampling karena sampel yang diambil yaitu siapa saja yang kebetulan ditemui cocok untuk dijadikan sebagai responden (Sugiyono, 2012) dengan kriteria orang tersebut merupakan konsumen buah alpukat di Kojama Shop. Teknik non probability sampling digunakan karena populasi tidak diketahui secara pasti jumlahnya dan tidak memungkinkan untuk mendapatkan probabilitas dari setiap elemen populasi (Yee, San, \& Khoon, 2010). Yee, et al. (2010) kemudian menjelaskan pengambilan sampel berdasarkan 
kenyamanan untuk menghemat waktu dan efisiensi biaya dengan proporsi populasi sasaran tidak dapat disimpulkan untuk keseluruhan populasi. Penentuan jumlah sampel yang diambil ditentukan menggunakan rumus Lemeshow. Rumus Lemeshow digunakan untuk menghitung ukuran sampel pada keadaan jumlah populasi yang tidak diketahui (Lemeshow, Hosmer, Klar, \& Lwanga, 1990). Perhitungan dengan rumus Lemeshow adalah sebagai berikut:

$n=\frac{Z^{2} x P(1-P)}{d^{2}}$

\section{Keterangan:}

$\mathrm{n}$ : Ukuran sampel

$\mathrm{Z}: 1,96$ score pada tingkat signifikansi tertentu (dengan derajat keyakinan 95\%)

$\mathrm{P}$ : Proporsi populasi $(50 \%$ atau 0,5$)$

Ketika peneliti tidak mengetahui tingkat $\mathrm{P}$ dalam populasi, maka disarankan menggunakan nilai maksimal estimasi 50\% atau 0,5 karena akan selalu memberi hasil pengamatan yang cukup terlepas dari nilai proporsi populasi yang sebenarnya (Lemeshow et al, 1990).

$\mathrm{d}$ : Tingkat kesalahan yang dapat ditoleransi maksimal (10\%).

Melalui perhitungan, diperoleh sampel sebanyak 100 responden.

Analisis regresi liniear berganda pada penelitian ini digunakan untuk memodelkan hubungan antar variabelvariabel dependen dengan variabel independennya. Variabel independen yang diteliti pada penilitian ini adalah kualitas produk, harga, dan citra merek sedangkan variabel dependennya adalah keputusan pembelian. Regresi Linear Berganda digunakan untuk menguji pengaruh dua atau lebih variabel independent terhadap satu variabel dependen (Janie, 2012). Analisis regresi linear berganda dapat dilakukan apabila data memiliki skala interval atau rasio, sedangkan pada penelitian ini data memiliki skala ordinal. Ningsih \& Dukalang (2019) menjelaskan bahwa analisis regresi linear berganda dapat tetap dilakukan pada data berskala ordinal apabila data ditransformasi menjadi skala interval menggunakan Metode Suksesif Interval (MSI). Pada penelitian ini data yang didapat ditransformasi terlebih dahulu menggunakan MSI pada aplikasi excel. Adapun secara sistematik analisis linier berganda sebagai berikut:

$$
Y=a+b 1 \times 1+b 2 \times 2+b 3 \times 3+e
$$

Keterangan :

Y $\quad$ : Keputusan Pembelian

a : Konstanta

$x 1 \quad$ : Kualitas Produk

$x 2 \quad$ : Harga Produk 
x3 : Citra Merek

blb2b3 : Koefisian Regresi

e $\quad$ : standar error

Teknik yang digunakan pada penelitian ini adalah survei. Survei dilakukan dengan memberikan kuesioner dengan metode skala likert kepada konsumen yang pernah membeli buah alpukat mentega di Kojama Shop. Menurut Sugiyono (2012), skala likert digunakan untuk mengukur sikap, pendapat, dan persepsi individu atau sekelompok individu tentang suatu fenomena. Jawaban pada setiap item instrumen menggunakan skala likert mempunyai gradasi dari sangat positif hingga sangat negatif. Perhitungan rentang skala dalam menentukan kepercayaan menggunakan rumus berikut:

$\frac{n-1}{5}=\frac{5-1}{5}=0,8$

Jadi, rentang skala untuk tingkat kepercayaannya adalah

$1-1,08 \quad$ : Sangat tidak baik

$1,81-2,60 \quad$ :Tidak baik

2,61-3,40 : Cukup baik

$3,41-4,20$ : Baik

4,21-5,00 : Sangat baik

Teknik analisis data yang digunakan adalah program aplikasi statistik yaitu software SPSS (Statistic for Prodict and Service Solution) untuk pengukuran uji validitas dan uji reliabilitas.

\section{HASIL DAN PEMBAHASAN}

\section{Karakteristik Responden}

Setelah melakukan penghitungan dengan rumus tersebut, diperoleh hasil jumlah sampel sebanyak 100 responden. Untuk mengetahui profil dari responden tersebut, maka penguji menggunakan karakteristik responden. Karakteristik yang dilihat berupa jenis kelamin, usia, domisili, tingkat pendidikan terakhir, status pernikahan, pekerjaan, dan pendapatan per bulan. Hasil penelitian tertera pada Tabel 1.

Responden yang merupakan konsumen buah alpukat di Kojama Shop didominasi oleh jenis kelamin wanita. Kandungan asam folat yang terdapat dalam buah alpukat merupakan nutrisi penting yang dibutuhkan oleh ibu hamil serta dapat mengurangi risiko keguguran dan cacat lahir pada bayi. Selain itu alpukat juga sering dijadikan sebagai makanan pendamping ASI untuk anak bayi. Konsumen dengan kelompok usia 26-35 tahun mendominasi disusul dengan kelompok usia 15-25 tahun merupakan masa dimana seorang wanita akan menikah, baru menikah, sedang menjalankan program kehamilan, sedang 
mengandung, ataupun memiliki anak bayi. Konsumen buah alpukat mentega Kojama Shop didominasi oleh konsumen yang berdomisili di Kota Jakarta. Hal tersebut terjadi dikarenakan Kojama Shop sendiri bertempat di Jakarta Timur sehingga untuk ongkos kirim yang lebih murah, mudah dan estimasi pengiriman yang lebih cepat ke sesama Jakarta dibandingkan ke luar Jakarta. Mayoritas konsumen merupakan lulusan S1, sudah menikah, bekerja sebagai pelajar/mahasiswa, dan berpendapatan lebih dari Rp3.000.000.

Tabel 1. Karakteristik Responden

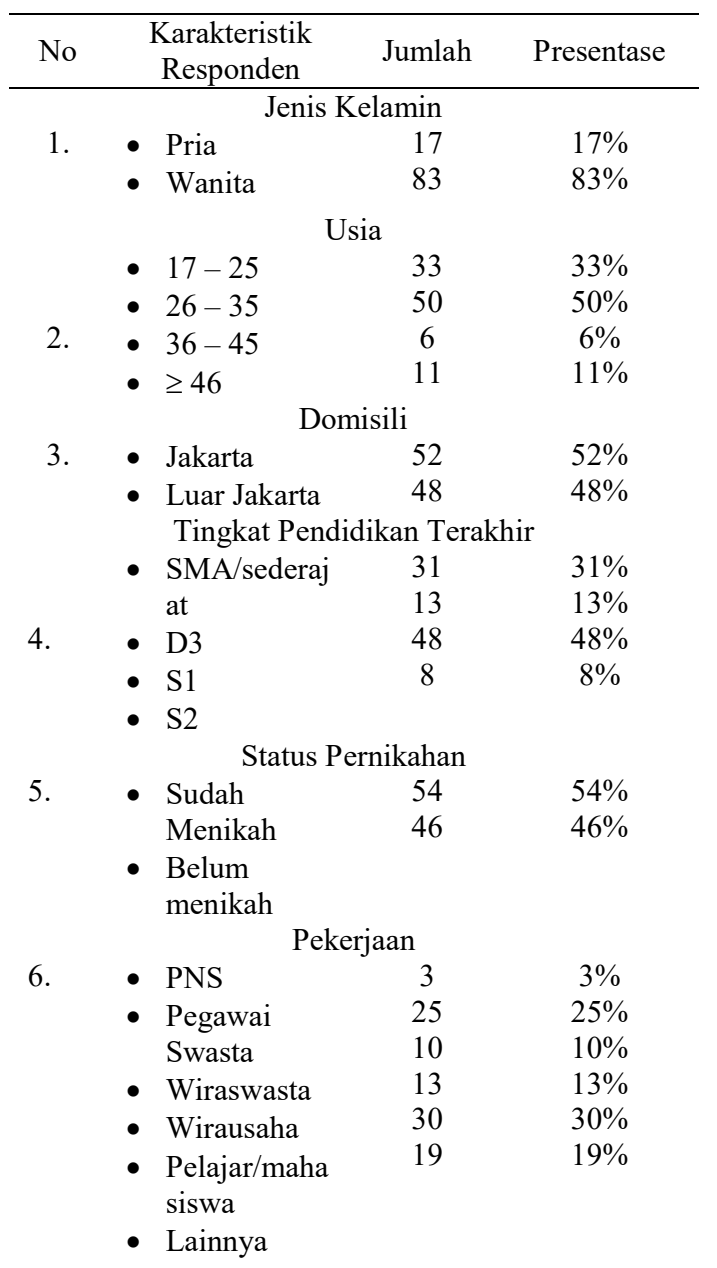

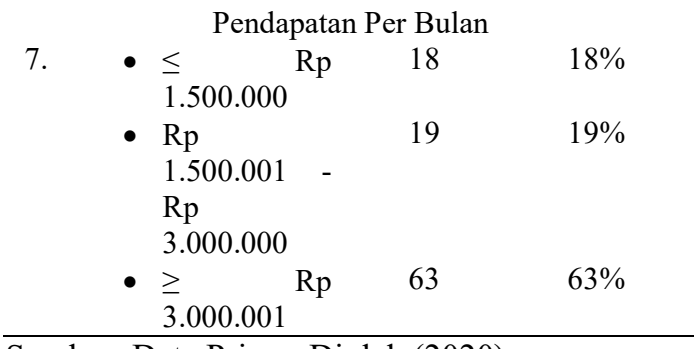

Sumber: Data Primer Diolah (2020)

\section{Uji Asumsi Klasik}

Uji normalitas dilakukan untuk mengetahui residual yang diteliti berdistribusi secara normal atau tidak. Nilai residual berdistribusi normal apabila data menyebar di sekitar grafik histogram atau garis diagonal pada diagram P-P Plot Regression Standarized Residual, sehingga model regresi dapat memenuhi asumsi normalitas (Janie, 2012).

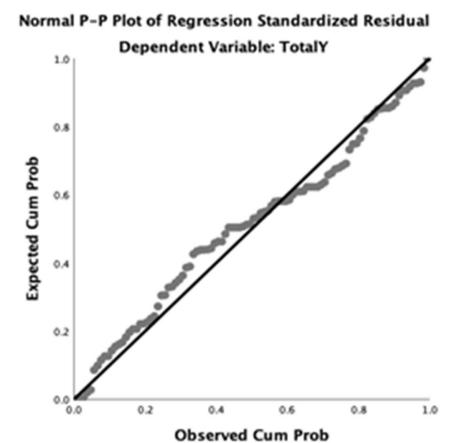

\section{Gambar 1. Grafik Uji Normalitas}

Titik-titik yang digambarkan pada grafik berada di sekitar garis diagonalnya, sehingga dapat disimpulkan bahwa model regresi pada penelitian ini memenuhi asumsi normalitas.

Model regresi dapat diterima apabila tidak terjadi multikolinearitas 
pada model regresi tersebut. Gejala multikolinearitas dapat dilihat melalui nilai Variance Inflation Factor (VIF) dan nilai tolerance. Apabila nilai VIF kurang dari sepuluh dan nilai tolerance lebih dari 0,1 maka tidak terdapat gejala multikolinearitas.

Hasil uji multikolinearitas menunjukkan bahwa seluruh variabel memiliki nilai VIF $<10$ dan nilai tolerance $>0,1$, sehingga dapat disimpulkan bahwa tidak terdapat gejala multikolinearitas pada model regresi penelitian ini.

Tabel 2. Hasil Uji Multikolinearitas

\begin{tabular}{|c|c|c|c|c|c|c|c|c|}
\hline \multirow{2}{*}{\multicolumn{2}{|c|}{ Model }} & \multicolumn{2}{|c|}{$\begin{array}{c}\text { Unstandardized } \\
\text { Coefficients }\end{array}$} & \multirow{2}{*}{$\begin{array}{c}\text { Standardized } \\
\text { Coefficients } \\
\text { Beta }\end{array}$} & \multirow[t]{2}{*}{$\mathrm{t}$} & \multirow[t]{2}{*}{$p$-value } & \multicolumn{2}{|c|}{$\begin{array}{c}\text { Collinearity } \\
\text { Statistics }\end{array}$} \\
\hline & & B & Std. Error & & & & Tolerance & VIF \\
\hline \multirow[t]{4}{*}{1} & (Constant) & 1.211 & 2.044 & & .593 & .555 & & \\
\hline & TotalX1 & .146 & .047 & .254 & 3.097 & .003 & .589 & 1.699 \\
\hline & TotalX2 & .258 & .085 & .234 & 3.056 & .003 & .676 & 1.480 \\
\hline & TotalX3 & .511 & .084 & .462 & 6.050 & .000 & .682 & 1.467 \\
\hline
\end{tabular}

Model regresi yang dapat diterima adalah apabila tidak terdapat heteroskedastisitas pada model regresi tersebut dimana varian dari residual pengamatan satu ke pengamatan lainnya adalah tetap. Hasil uji heteroskedastisitas dapat dilihat pada Gambar 2.

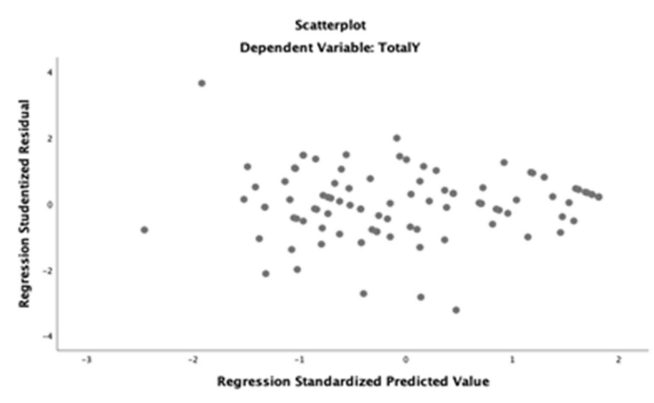

Gambar 2. Grafik Uji Heteroskedastisitas

Model regresi yang baik adalah ketika grafik scatterplot yang muncul tidak memiliki pola tertentu, seperti berkumpul ditengah, menyempit, atau membesar.

\section{Uji Regresi Linear Berganda}

Uji $\mathrm{F}$ bertujuan untuk mengetahui apakah variabel independen secara bersama-sama berpengaruh positif terhadap variabel dependen. Hasil pengujian Uji $\mathrm{F}$ dapat dilihat pada Tabel 3.

Tabel 3. Hasil Uji F

\begin{tabular}{|c|c|c|c|c|c|c|}
\hline \multicolumn{2}{|c|}{ Model } & \multirow{2}{*}{$\begin{array}{r}\begin{array}{c}\text { Sum of } \\
\text { Squares }\end{array} \\
901.644\end{array}$} & \multirow{2}{*}{$\begin{array}{r}\mathrm{df} \\
3\end{array}$} & \multirow{2}{*}{$\begin{array}{l}\begin{array}{c}\text { Mean } \\
\text { Square }\end{array} \\
300.548\end{array}$} & \multirow{2}{*}{$\begin{array}{c}\mathrm{F} \\
51.882\end{array}$} & \multirow{2}{*}{$\frac{p \text {-value }}{.000^{\mathrm{b}}}$} \\
\hline 1 & Regression & & & & & \\
\hline & Residual & 556.124 & 96 & 5.793 & & \\
\hline & Total & 1457.769 & 99 & & & \\
\hline
\end{tabular}


Nilai $F$ tabel didapat dengan melihat nilai distribusi $\mathrm{F}$ tabel dengan probabilita 0,5 . Nilai $\mathrm{F}_{\text {tabel }}(\mathrm{k} ; \mathrm{n}-\mathrm{k})=\mathrm{F}(3$ ; 97) $=2,70$. Melalui Tabel 3 diketahui nilai $p$-value $=0,000<\alpha=0,05$ dan nilai $\mathrm{F}_{\text {hitung }}=51,882>\mathrm{F}_{\text {tabel }}=2,70$, sehingga disimpulkan bahwa variabel kualitas, harga, dan citra merek secara bersamasama berpengaruh signifikan terhadap keputusan pembelian buah alpukat mentega di Kojama Shop.
Uji t digunakan untuk mengetahui besarnya pengaruh masing-masing variabel independen secara parsial terhadap variabel dependen. Nilai dari uji t dapat diketahui dengan melihat $p$-value atau nilai t-hitung. Apabila $p$-value lebih kecil dari $\alpha=0,05$ atau nilai $t_{\text {hitung }}$ lebih besar daripada $\mathrm{t}_{\text {tabel }}(\alpha / 2 ; \mathrm{n}-\mathrm{k}-1)=\mathrm{t}(0,025$ ;96) $=1,98$ maka variabel independen dapat dikatakan berpengaruh nyata terhadap variabel dependen. Hasil Uji t dapat dilihat pada Tabel 4.

Tabel 4. Hasil Uji t

\begin{tabular}{|c|c|c|c|c|c|c|c|c|}
\hline \multirow{2}{*}{\multicolumn{2}{|c|}{ Model }} & \multicolumn{2}{|c|}{$\begin{array}{c}\text { Unstandardized } \\
\text { Coefficients }\end{array}$} & \multirow{2}{*}{$\begin{array}{c}\text { Standardized } \\
\text { Coefficients } \\
\text { Beta }\end{array}$} & \multirow{2}{*}{$\mathrm{t}$} & \multirow{2}{*}{ p-value } & \multicolumn{2}{|c|}{$\begin{array}{c}\text { Collinearity } \\
\text { Statistics }\end{array}$} \\
\hline & & B & Std. Error & & & & Tolerance & VIF \\
\hline \multirow[t]{4}{*}{1} & (Constant) & 1.211 & 2.044 & & .593 & .555 & & \\
\hline & Kualitas produk & .146 & .047 & .254 & 3.097 & .003 & .589 & 1.699 \\
\hline & Harga produk & .258 & .085 & .234 & 3.056 & .003 & .676 & 1.480 \\
\hline & Citra Merek & .511 & .084 & .462 & 6.050 & .000 & .682 & 1.467 \\
\hline
\end{tabular}

Berdasarkan pada hasil perhitungan SPSS yang terdapat pada Tabel 4, $p$-value masing-masing variabel kualitas produk $=0,003$, harga produk $=0,003$, dan citra merek $=0,000$ lebih kecil dari $\alpha=0,05$ dan nilai t-hitung variabel kualitas produk $=$ 3,097 , harga produk $=3,056$, dan citra merek $=6,050$ seluruhnya memiliki nilai lebih besar dari 1,98. Kesimpulannya variabel kualitas produk, harga produk, dan citra merek memiliki pengaruh positif dan signifikan terhadap variabel keputusan pembelian. Persamaan model regresi linier yang terbentuk adalah sebagai berikut:

$\mathrm{Y}=1,211+0,146 \mathrm{X}_{1}+0,258 \mathrm{X}_{2}+$ $0,511 X_{3}+\varepsilon$

$\mathrm{Y} \quad$ : Keputusan pembelian

$\mathrm{X}_{1} \quad$ : Kualitas produk

$\mathrm{X}_{2} \quad$ : Harga produk

$\mathrm{X}_{3} \quad$ : Citra merek 
$\varepsilon \quad: \quad$ Variabel lain yang mempengaruhi keputusan pembelian yang tidak terdapat pada persamaan linier.

Berdasarkan persamaan tersebut dapat dijelaskan bahwa :

1. Apabila variabel kualitas $\left(X_{1}\right)$, harga $\left(\mathrm{X}_{2}\right)$, dan citra merek $\left(\mathrm{X}_{3}\right)$ dianggap nol atau konstan, maka nilai keputusan pembelian (Y) adalah 1,211 .

\section{Variabel Kualitas Produk Berpengaruh Positif Terhadap Keputusan Pembelian.}

Koefisien regresi variabel kualitas produk $\left(\mathrm{X}_{1}\right)$, adalah sebesar 0,146 , nilai koefisien ini bersifat positif yang artinya terdapat hubungan yang searah antara variabel kualitas dengan keputusan pembelian. Hal tersebut mengindikasikan bahwa semakin baik persepsi responden mengenai kualitas maka keputusan pembelian akan meningkat.

\section{Penelitian Rochaeni} menemukan bahwa persepsi konsumsi buah lokal meliputi kualitas dan rasa buah, rasa buah lokal dinilai memiliki rasa yang lebih segar dibandingkan buah impor sehingga konsumen melakukan pembelian. Sejalan dengan penelitian Laoli dan Hasan (2020) dan Ulum, et al. (2019) yang mengatakan kualitas produk berpengaruh positif terhadap keputusan pembelian suatu produk. Penelitian Sembiring (2016), Widyastuti (2018), dan Masyadi, et al. (2020) juga menunjukkan kualitas produk memiliki pengaruh positif terhadap pembelian produk pertanian baik buah ataupun sayur. Sesuai dengan karakteristik produk pertanian yang dikemukakan oleh Bulsara dan Trivedi (2016) yaitu mudah rusak, maka konsumen akan memperhatikan kualitas produk yang akan dibeli.

Kualitas produk bepengaruh signifikan terhadap keputusan pembelian artinya semakin baik kualitas maka keputusan pembelian akan semakin tinggi pula (Smith \& Paladino, 2010). Pada penelitian ini, responden menyatakan bahwa kualitas buah alpukat mentega yang dimiliki Kojama Shop sudah sesuai dengan keinginan mereka, sehingga memutuskan untuk membeli buah alpukat mentega di Kojama Shop. Responden sudah percaya pada kualitas produk yang dijual oleh Kojama Shop.

\section{Variabel Harga Produk \\ Berpengaruh Positif Terhadap Keputusan Pembelian.}

Koefisien regresi variabel harga produk $\left(\mathrm{X}_{2}\right)$ adalah sebesar 0,255 , nilai koefisien ini bersifat positif yang artinya 
terdapat hubungan yang searah antara variabel kualitas dengan keputusan pembelian. Hal tersebut mengindikasikan bahwa semakin kompetitif harga yang ditawarkan oleh perusahaan maka keputusan pembelian yang dilakukan oleh responden akan meningkat (Pitaloka, 2015).

Penelitian ini berbeda dengan hasil penelitian yang dilakukan oleh Mahanani (2018) menyatakan bahwa variabel harga berpengaruh negatif terhadap keputusan pembelian. Mahanani (2018) lebih jelas mengatakan semakin tinggi harga yang ditawarkan akan menurunkan keputusan pembelian karena harga yang ditawarkan masih dianggap mahal dan objek penelitiannya adalah produk pakaian pada website mataharimall.com. Penelitian ini sejalan dengan penelitian Sembiring (2016), Darmawan (2017), dan Widyastuti (2018) bahwa harga berpengaruh positif dan signifikan terhadap pembelian produk pertanian.

Widyastuti (2018) dalam penelitiannya mengenai pengaruh harga terhadap keputusan pembelian sayuran organik mengatakan bahwa manfaat lebih yang dimiliki suatu produk dengan harga yang sesuai pasaran menjadi pertimbangan konsumen untuk membeli produk. Kojama Shop sebagai perusahaan menetapkan harga produknya sesuai dengan kualitas dan pelayanan yang diberikan, sehingga responden merasa bahwa harga yang dibayarkan adalah sesuai dengan manfaat dan kualitas yang didapat. Apabila konsumen menerima harga yang ditetapkan oleh perusahaan, maka produk akan lebih banyak terjual. Sebaliknya apabila harga yang ditetapkan ternyata tidak sesuai dengan kualitas dan manfaat yang diterima konsumen, sehingga menyebabkan produk tidak laku, maka diperlukan peninjauan kembali mengenai harga yang ditetapkan oleh perusahaan.

Mayoritas responden yang merupakan konsumen buah alpukat mentega Kojama Shop setuju bahwa harga alpukat mentega Kojama Shop sesuai dengan manfaat yang dirasakan, memiliki daya saing dengan merek lain yang sejenis, dan harga yang konsumen bayarkan sesuai dengan kualitas yang didapat.

\section{Variabel Citra Merek Berpengaruh Positif Terhadap Keputusan Pembelian.}

Koefisien regresi variabel citra merek $\left(X_{3}\right)$ adalah sebesar 0,511 , nilai koefisien ini bersifat positif yang artinya terdapat hubungan yang searah antara variabel citra merek dengan keputusan 
pembelian. Hal tersebut mengindikasikan bahwa semakin baik persepsi responden mengenai kualitas maka keputusan pembelian akan meningkat. Faktor citra merek merupakan faktor yang paling berpengaruh. Hal tersebut dapat dilihat pada koefisien citra merek yang paling besar.

Rubini (2010) pada penelitiannya menyebutkan bahwa keputusan akhir pembelian konsumen dipengaruhi oleh citra merek yang dibawa oleh suatu brand. Penelitian ini sejalan dengan penelitian Mahanani (2018), Hakim dan Saragih (2019), Lesmana (2019) yang menunjukkan bahwa citra merek berpengaruh positif dan signifikan terhadap keputusan pembelian produk. Berbeda dengan penelitian Hakim dan Susilowati (2013) mengenai pengaruh citra merek terhadap keputusan pembelian produk pestisida, citra merek berpengaruh namun tidak signifikan terhadap keputusan pembelian. Hakim dan Susilowati (2013) lebih lanjut menjelaskan, hal tersebut terjadi karena konsumen membeli produk berdasarkan pada fungsinya tanpa memperhatikan faktor lain dari produk seperti kesenangan atau manfaat lainnya.

$$
\text { Persepsi citra merek juga }
$$
merupakan variabel yang paling berpengaruh pada keputusan pembelian buah alpukat mentega di Kojama Shop dibuktikan dengan koefisien pada model regresinya yang paling besar yaitu sebesar 0,511. Hal tersebut mengindikasikan bahwa sebesar 51,1\% keputusan pembelian alpukat mentega yang dilakukan oleh responden dipengaruhi oleh citra merek, sedangkan 48,9\% sisanya dipengaruhi oleh variabel diluar citra merek.

Besarnya pengaruh presentase variabel bebas terhadap variabel terikat dapat dilihat pada Tabel 5.

Tabel 5. Hasil Koefisien Determinasi

\begin{tabular}{lrrrr}
\hline Model & R & R Square & $\begin{array}{c}\text { Adjusted R } \\
\text { Square }\end{array}$ & $\begin{array}{c}\text { Std. Error } \\
\text { of the } \\
\text { Estimate }\end{array}$ \\
\hline 1 & $.786^{\mathrm{a}}$ & .619 & .607 & 2.406857 \\
\hline
\end{tabular}

Pada Tabel 5 diketahui bahwa nilai koefisien determinasi $\left(\mathrm{R}^{2}\right)$ adalah sebesar 0,619 yang berarti variabel keputusan pembelian dipengaruhi oleh variabel kualitas, harga, dan citra merek sebesar $61,9 \%$ sedangkan $\quad 38,1 \%$ sisanya dipengaruhi oleh variabel lain yang tidak diteliti pada penelitian ini.

\section{KESIMPULAN DAN SARAN}

\section{Kesimpulan}

1. Sebanyak 100 responden yang merupakan konsumen buah alpukat mentega Kojama Shop mayoritas 
adalah wanita dengan rentang usia 2636 tahun yang berdomisili di Jakarta dengan tingkat pendidikan terakhir adalah S1, bekerja sebagai pelajar/mahasiswa dan karyawan, dan berpendapatan lebih dari $\mathrm{Rp}$ 3.000 .000

2. Ketiga variabel kualitas produk, harga, dan citra merek berpengaruh positif dan signifikan terhadap keputusan pembelian dengan citra merek merupakan variabel yang paling dominan berpengaruh sedangkan kualitas produk merupakan variabel yang tidak dominan berpengaruh terhadap keputusan pembelian.

\section{Keterbatasan Penelitian}

1. Metode pengumpulan data pada penelitian ini tidak dapat mewakili populasi yang sebenarnya dari responden yang menjadi sasaran karena metode pengambilan sampel convinience sampling yang menyebabkan sampel tidak dapat diambil secara acak dan memungkinkan bersifat subjektif sehingga penelitian ini tidak dapat digeneralisasi untuk mewakili seluruh populasi konsumen Kojama Shop.

2. Penelitian ini hanya meneliti kualitas produk, harga, dan citra merek yang berpengaruh terhadap keputusan pembelian. Masih terdapat indikator lain yang berpengaruh terhadap keputusan pembelian seperti pelayanan, kepuasan konsumen, promosi, dan packaging.

\section{Saran}

1. Bagi Perusahaan

a. Citra merek merupakan faktor yang paling baik dan diperhatikan konsumen dalam melakukan pembelian di Kojama Shop, sehingga Kojama Shop perlu untuk mempertahankan citra merek yang sudah dibangun dan terus melakukan inovasi seperti mengadakan campaign atau gerakan hidup sehat dengan cara mengonsumsi buah-buahan lokal salah satunya alpukat mentega agar citra merek yang sudah dibentuk semakin baik dan tidak menurun.

2. Bagi Peneliti Selanjutnya

a. Peneliti selanjutnya dapat mengembangkan penelitian dengan meneliti variabel lain yang dapat mempengaruhi keputusan pembelian di Kojama Shop, misalnya seperti packaging, promosi penjualan, pelayanan, kepuasan konsumen dan lain sebagainya.

b. Peneliti selanjutnya bisa menggunakan metode lain seperti 
wawancara mendalam dengan konsumen sehingga mendapatkan informasi yang lebih mendetail.

c. Peneliti selanjutnya juga dapat mengembangkan proses keputusan pembelian lainnya seperti pengenalan kebutuhan, pencarian informasi, evaluasi, dan perilaku pasca pembelian.

\section{DAFTAR PUSTAKA}

Anderson, D. R., Sweeney, D. J., \& Williams, T. A. (2011). Statistic for Business and Economics. Ohio: South Western Cengage Learning.

Bulsara, H. P., \& Trivedi, K. G. (2016). An Exploratory study of factors related to Consumer Behaviour towards purchase of Fruits and Vegetables from different Retail Formats. Journal of Research in Marketing, 6(1), 397-406.

Sugiyono. (2012). Metode Penelitian Kuantitatif, Kualitatif, dan $R \& D$. Bandung: Alfabeta.

Yee, C. J., San, A. N., \& Khoon, C. H. (2010). A Study on Malaysia Consumer Perception towards Buying an Automobile. 290-295.

Lemeshow, S., Hosmer, D. W., Klar, J., \& Lwanga, S. K. (1990). Adequacy of Sample Size in Health Studies. Cichester: John Wiley \& Sons Ltd

Janie, D. N. (2012). Statistik deskriptif \& regresi linier berganda dengan SPSS. Jurnal, April.

Ningsih, S., \& Dukalang, H. (2019). Penerapan Metode Suksesif Interval pada Analsis Regresi Linier Berganda. Jambura Journal of Mathematics, 1(1), 43-53.

Rochaeni, S. (2013). Analisis Persepsi, Kesadaran, dan Preferensi
Konsumen Terhadap Buah Lokal. Jurnal Agribisnis, 7(1), 91-104.

Laoli, Y., \& Hasan, S. (2020). Pengaruh Kualitas Produk, Harga, dan Promosi Terhadap Keputusan Pembelian Air Minum Dalam Kemasan Di Kota Bangkinang. Jurnal Riset Manajemen Indonesia, 2(1), 50-59.

Ulum, M. B., Rachma, N., \& ABS, K. (2019). Analisis Pengaruh Harga, Kualitas Produk, dan Lokasi Terhadap Keptusuan Pembelian (Suatu Kasus Konsumen Lapis Tugu Malang). Jurnal Riset Manajemen, 8(20), 25-33.

Widyastuti, P. (2018). Kualitas dan Harga sebagai Variabel Terpenting pada Keputusan Pembelian Sayuran Organik. Ekspektra: Jurnal Bisnis dan Manajemen, 2(1), 17-28.

Sembiring, R. (2016). Pengaruh Harga, Kualitas, Keragaman Produk dan Lokasi Pasar Terhadap Preferensi Konsumen Dalam Membeli Produk Pertanian di Pasar Tradisional Berastagi. Agrica (Jurnal Agribisnis Sumatera Utara), 9(2), 107-116.

Masyadi, Salam, A., \& Masri, Y. (2020). Pengaruh Promosi dan Kualitas Terhadap Keputusan Pembelian Buah Naga di Kecamatan Donri Donri Kabupaten Soppeng. Jurnal Ilmiah METANSI "Manajemen dan Akuntansi", 3(2), 61-67.

Smith, S., \& Paladino, A. (2010). Eating clean and green? Investigating consumer motivations towards the purchase of organic food. Australasian Marketing Journal, 18(2), 93-104.

Pitaloka, A. F. (2015). Pengaruh Kualitas Pelayanan, Harga, dan Promosi Terhadap Penjualan Online Shop Busana Muslim. Jurnal Ilmu dan Riset Manajemen, 4(1), 1-19. 
Mahanani, E. (2018). Pengaruh Citra Merek, Kualitas Produk, Harga, dan Gaya Hidup Terhadap Keputusan Pembelian Produk Mataharimall.com. IKRA-ITH HUMANIORA: Jurnal Sosial dan Humaniora, 2(1), 53-61.

Darmawan, D. (2017). Pengaruh Kemasan dan Harga Terhadap Keputusan Pembelian Produk Sayuran Hidroponik. Agrimas, 1(1), 1-10.

Rubini, A. (2010). Role of Brand in Consumer Behavior. Case: How Sneakers Have Turned into Status Symbols. [Tesis]. Kuopio: Degree Programme Savonia University of Applied Science
Hakim, L., \& Saragih, R. (2019). Pengaruh Citra Merek, Persepsi Harga, dan Kualitas Produk Terhadap Keputusan Pembelian Konsumen NPK Mutiara di UD.Barelang Tani Jaya Batam. Jurnal Ecobisma, 6(2), 37-53.

Lesmana, R. (2019). Pengaruh Kualitas Produk dan Citra Merek Terhadap Keputusan Pembelian Kosmetik Wardah PT Paragon Technology And Innovation. Jurnal Pemasaran Kompetitif, 2(3), 59-72.

Hakim, R. T., \& Susilowati, C. (2013). Pengaruh Persepsi Iklan, Kesadaran Merek, Citra Merek terhadap Sikap pada Merek dan Keputusan Pembelian (Studi pada Produk Pestisida Merek Sidamethrin 50 EC). Jurnal Aplikasi Manajemen, 11(4), 537-546. 